\title{
Custody Transfers of Children and Young Adults in Foster Care
}

\author{
Helen Blomé * and Majen Espvall
}

\author{
Department of Psychology and Social Work, Mid-Sweden University, S-831 25 Östersund, Sweden; \\ majen.espvall@miun.se \\ * Correspondence: helen.blome@miun.se; Tel.: +46-10-142-83-62
}

\begin{abstract}
The high-profile case of "Little Heart", a 3-year-old girl who, shortly after being reunited with her biological parents, was found dead in her home, has contributed to strengthening the rights of children placed in foster care in Sweden. However, the stability of children placed in foster care is not a new issue. In the last decade, the number of custody transfers has more than doubled. In this study, critical discourse analysis was used to study which discourses on children's needs and parental rights had guided 89 district court decisions. The results show that custody transfer takes place at a younger age and is still based on an adult perspective, and children's voices and wishes are often overlooked. The dominant discourses in the submissions of the social services, as well as in the district court decisions, are about continuity, connection, and security, concepts and formulations that are replicated from the preparatory work for the legislation. This study demonstrates the need for expertise and reflection in custody investigations into how questions are asked and how the responses are conveyed, as well as the need to intensify and strengthen the work of making children involved and heard in accordance with the aims of the Children's Convention.
\end{abstract}

Keywords: foster care; custody transfer; child's best interests; critical discourse analysis

check for

updates

Citation: Blomé, Helen, and Majen Espvall. 2021. Custody Transfers of Children and Young Adults in Foster Care. Genealogy 5: 80. https:// doi.org/10.3390/genealogy5030080

Received: 14 June 2021

Accepted: 29 August 2021

Published: 2 September 2021

Publisher's Note: MDPI stays neutral with regard to jurisdictional claims in published maps and institutional affiliations.

\section{Introduction}

In spring 2020, the "Little heart" case attracted attention in the Swedish media. Little Heart, or Esmeralda, was placed in foster care directly after her birth. When she was just over 3 years old, Esmeralda was reunited with her biological parents, and shortly thereafter, she was found dead in her home. After this tragedy, critical voices were directed at incompetent social workers, lawyers, and courts, as well as at a private market comprising ignorant counsels (see, for example, Lagercrantz 2020; Fyhr 2020; Carlemalm 2020). Despite the fact that the case was unique in many respects, Esmeralda's life story came to raise questions about how custody transfers are handled by the Swedish social services. Consequently, in March 2021, the legislation regarding custody transfer was strengthened with the intention that the social services should consider custody transfers to a greater extent and thereby increase the stability for children in foster care (Government Bill 2020, 21:35).

Stability and continuity for children in need of long-term foster care is not a new issue. Since 2003, the social services have had a special responsibility for considering reasons for transferring custody to foster parents (Government Bill 2002, 03:53). A challenge for the social services is to assess the best interests of the child and need for continuity, as well as the parents' rights and ability as guardians (National Board of Health and Welfare 2006). In this process, the child has a right to information, to be heard, and to have his or her opinions taken into account (SFS 2001, 453, Social Services Act). If the social services investigation shows that a change of custody, from the biological parents to the foster parents, is in the best interests of the child, the matter is decided by the district court following an application from the social services. In short, a custody transfer means that the foster parents (as guardians) have full responsibility for the child's personal situation without further involvement from the social services and that the biological parent has no right to change, or end, the placement. 
Initially, the change in the law had relatively little effect. However, over the last few decades, the number of custody transfers has more than doubled, from 125 to 340 during the period 2005 to 2019 (National Board of Health and Welfare 2006, 2020). During the same period, market-orientated management principles, New Public Management (NPM), have had a major impact on both the legal system and the social services in Sweden (Thunman 2016; Sallnäs and Wiklund 2018). For social workers, the new governing doctrines are about balancing seemingly incompatible demands. The professional practice, whose premises are based on knowledge, research, and ethical values, has to compete with the requirements of organisational professionalism in which cost-effectiveness, administrative skills, and manual application are prioritised (Ponnert and Svensson 2015; Lauri 2016; Espvall 2018). At best, the increase in custody transfers reflects the development of the professional skills needed to investigate and assess the conditions for custody transfers; at worst, it is a consequence of cases being handled more routinely and has therefore enabled more investigations and district court cases.

The issue of custody transfers for children placed in foster care touches on two conflicting interests: children's need for continuity and sense of belonging to the foster parents, and the biological parents' desire to be reunited with their child and/or desire to remain as guardians. For social workers and the courts, it is a matter of weighing children's right to stable and proper conditions for growing up against parents' ability to exercise their parenthood. As a guide, there are explicit and implicit formulations in the legal texts and preparatory work that, together, create a discursive understanding of what child wellbeing means, and that become decisive for its application in social practice, i.e., in the assessments conducted by the social services and the courts. Thus, the way in which concepts and statements are created, reproduced, and understood has decisive consequences for the safeguarding of the individual child, as well as the rights of parents.

This study analyses district court decisions from 2014-2016 that addressed the issue of custody transfer from birth parents to foster parents. The purpose of the study was to investigate which discourses about children's needs and parental rights have guided district court decisions on custody transfer. The key issues are as follows: (1) To what extent and in which cases are custody transfers applied? (2) What concepts and linguistic representations are used to shape children's needs and parental rights, and what kind of discursive practices do these represent? (3) What is the significance of these discursive practices for social practice, i.e., for the assessments of the social services and the court?

The aim of custody transfer legislation is to prevent children who perceive a foster home as their home from being removed from their habitual environment. The importance of investigating the child's connection to the foster home is emphasized, and not least, the child's own wishes are of paramount importance. However, a custody transfer does not require a parent to be unsuitable as a parent. Other reasons that may represent the child's best interests may mean that the parents are deprived of custody (Goverment Bill 1981, 82:168). At the same time, the preparatory work highlights the desire for children to be reunited with their biological parents and that a custody transfer should not be considered if the parents maintain good contact with the child in foster care. This article shows that custody transfers are still viewed from an adult perspective and that children's rights and will are often neglected. Furthermore, our analysis shows the importance of social services and courts carefully considering which concepts and statements are applied and given meaning in investigations concerning custody transfers.

\section{Previous Research}

Despite the fact that custody transfers are increasingly being used in Sweden, research in this field, both internationally and nationally, is still limited. A contributory factor for the field being overlooked internationally is that most other countries use adoption instead of custody transfers in such cases, which means that Sweden has a somewhat unique positioning on these issues (SOU 2009, 68). In a long-term perspective, there are crucial differences, as foster parents' obligations in the event of a custody transfer cease once the 
child has reached 18 years of age, whereas adoptive parents maintain their role as parents for life. However, this does not prevent some international research on adoption from being relevant in this context.

International studies that examine the legal changes in custody show the importance of offering children in foster care love, support, stability, attachment, and a sense of belonging (Griffin 2004; Dozier and Lindheim 2006; Rolock and White 2016). These concepts have many connotations, but there is much to suggest that they are relevant, not to a particular place and a physical home, but in a child's social relations with their foster home, biological family, relatives, friends, and school (Biehal 2014; Risholm Mothander and Broberg 2015).

In addition to the National Board of Health and Welfare's follow-up of the social services' work with custody transfers (National Board of Health and Welfare 2006, 2015), a few studies have examined the issue in a Swedish context. Mattsson (2010) demonstrated what family affiliation associated with security and community means in a legal perspective. Mattsson noted here that the social services often delay applying for a custody transfer and that, in many cases, in view of the legislative requirements, decisions could be approved because the child had been "continuously raised in the foster home for many years" (Mattsson 2010, p. 155). Similarly, Wissö et al. (2019) noted that children placed in foster care often considered the foster home as their own home even before a custody transfer and that it was therefore difficult to draw conclusions as to whether the custody issue itself affected the child's perception of family affiliation. Wissö and Johansson (2018) also found the legislation ambiguous and that the child's view was absent in the majority of the court's decisions.

\section{Materials and Methods}

This study included a survey and a discourse analysis of district court decisions regarding custody transfers in Sweden. The survey identified the following key factors in court decisions from 2014 to 2016: the child's age at placement, the duration of placement, and the child's age at custody transfer. Furthermore, based on Fairclough's critical discourse analysis, the study analysed which discourses have guided claims made by social services and district court decisions.

The survey examined all district court decisions that handled cases in accordance with Section 8, Chapter 6 of the Swedish Children and Parent Code (SFS 1949, 381) from eight district courts; see Table 1 . The courts represent both large and small municipalities and are geographically located in different parts of the country. The documentation from the eight district courts includes a total of 89 decisions and affects 97 children and 115 parents.

Table 1. Decisions 2014-2016.

\begin{tabular}{cc}
\hline District Court & District Court Decisions \\
\hline Lycksele & 1 \\
Luleå & 13 (17 children) \\
Östersund & 5 \\
Värmland & 8 \\
Stockholm & 3 \\
Göteborg & 40 \\
Lund & 2 \\
Helsingborg & $17(22$ children $)$ \\
\hline Total & 89 ( 97 children $)$ \\
\hline
\end{tabular}

As the table shows, there are large variations in the numbers of cases handled by the various district courts during the relevant period (cf. National Board of Health and Welfare 2006). In total, 89 applications from the social services were approved by the district courts, meaning that the custody of the child was transferred from the birth parents to the foster parents. 


\subsection{Critical Discourse Analysis}

We used critical discourse analysis to study how concepts and statements become guidelines for social practice, i.e., in the handling of custody transfers. Critical discourse analysis, which defines language use as part of social practice, is often associated with the linguist Norman Fairclough (1992). Fairclough's analysis model, which contains three dimensions - text, discursive practice, and social practice-offers a theoretical framework and concrete methods for analysing empirical studies.

Text is about which words, statements, and grammar are used and, together, create a discourse. Discursive practice refers to the relationship between the current text and other texts and, in turn, the discourses on which these other texts are based. Discursive practice helps us to understand how texts are related to each other (in this case, how district court decisions relate to social services' investigations and the preparatory work for the legislation) and how they are produced and consumed, for example, who writes and reads the texts and how they can be understood.

Text analysis and discursive practice focuses on word choice and how concepts are borrowed, linked, and used, often for a legitimising purpose. Social practices constitute the broader context in which text and discursive practice are included. In this context, the analysis of social practice is about how text and discursive practice become decisive for social services' assessments and district court decisions.

In our analysis, we have particularly focused on the modality and intertextuality of the texts. The analysis of modality tells us about the position of the author who produced the text, i.e., whether something is being expressed subjectively or objectively. If a social worker chooses to write, "Carl thinks it is going well at school" or "Things are good at school", this will affect how the text is perceived, as a subjective experience or as an objective truth. Intertextuality involves the analysis of which previous discourses the texts are based on, and which references are being made to other texts. In our study, we investigated whether there were connections between preparatory work, research on children's needs, and the theories used in social practice.

Discourse analysis reveals three discursive practices, the best interests of the child, reunion and social relationships, and one home-one family. The first discursive practice included all 89 decisions in the analysis. The other two discursive practices included 20 decisions where the biological parent/parents opposed the custody transfer. The latter analysis of these discourses started from the assumption that different discourses were most obvious in decisions in which there was a conflict between the social services' assessment of the child's needs and the parents' desire to remain as guardians. In 25 decisions, the biological parent opposed the custody transfer, but five decisions handled siblings, in which the documents were almost identical, so only one member of the sibling group was included. Thus, a total of 20 decisions were included in the final analysis. In conducting the discourse analysis, a close reading of the decisions revealed which kind of statements are used, how often the statements are repeated, who uses the statements, and the meaning of them (the discursive practice). Finally, we conducted an analysis of how discursive practice can conceivably interact with, and influence, social practice in the transfer of custody. The district court decisions are written in Swedish, and the quotations have therefore been translated into English.

\subsection{Ethical Considerations}

District court decisions are in the public domain, even if parts of the judgment may be protected on the grounds of integrity. Nevertheless, it is important to treat the material sensitively and anonymise quotes and other descriptions in order to prevent children and families from being identified. When reporting the results, fictitious names are used and any information that could be traced to a person or district court is excluded. 


\section{Results}

\subsection{Application of the Law on Custody Transfers}

As previously mentioned, there has been an increase in the number of custody transfers in Sweden. Our survey shows that, today, the social services apply for custody transfers of both younger children and children who have been placed in a foster home later in life to a greater extent than previously, see Table 2. An analysis of decisions from 2005 to 2009 shows that the average age for the children in question during this period was 10.5 years (Mattsson 2010) and, then, as our study shows, dropped to just over 9 years from 2014 to 2016. The duration of placement in a foster home prior to a custody transfer decreased from an average of 7.5 years to 5.5 years during the current period.

Table 2. The child's age and duration of placement.

\begin{tabular}{|c|c|c|c|c|}
\hline \multirow[b]{2}{*}{ Age at the time of placement } & \multicolumn{2}{|c|}{ Survey 2014-2016 (8 District Courts) } & \multicolumn{2}{|c|}{$\begin{array}{l}\text { National Board of Health and Welfare } \\
\qquad 2000-2005 \text { (Total) * }\end{array}$} \\
\hline & $\%$ & $\mathrm{n}$ & $\%$ & $\mathrm{n}$ \\
\hline $0-1$ years & $44 \%$ & 43 & $44 \%$ & 198 \\
\hline $2-6$ years & $26 \%$ & 25 & $36 \%$ & 159 \\
\hline $7-12$ years & $24 \%$ & 23 & $19 \%$ & 83 \\
\hline 13-17 years & $2 \%$ & 2 & $1 \%$ & 6 \\
\hline Missing & $4 \%$ & 4 & & \\
\hline \multicolumn{5}{|l|}{ Duration of placement } \\
\hline $0-2$ years & $8 \%$ & 8 & & \\
\hline $3-6$ years & $67 \%$ & 65 & $37 \%$ & 163 \\
\hline $7-12$ years & $15 \%$ & 15 & $49 \%$ & 219 \\
\hline $13-17$ years & $5 \%$ & 5 & $14 \%$ & 64 \\
\hline Missing & $4 \%$ & 4 & & \\
\hline \multicolumn{5}{|c|}{ Age at the time of custody transfer } \\
\hline $0-2$ years & $7 \%$ & 7 & & \\
\hline $3-6$ years & $31 \%$ & 30 & $12 \%$ & 52 \\
\hline $7-12$ years & $30 \%$ & 29 & $45 \%$ & 201 \\
\hline 13-17 years & $32 \%$ & 31 & $43 \%$ & 193 \\
\hline
\end{tabular}

The division into age intervals follows the National Board of Health and Welfare's report. * National Board of Health and Welfare (2006).

In the decisions examined in this study, the district court in all cases upheld the social services' request for custody transfer. In the majority of the decisions, both parents agreed on the custody transfer (65\%); in a few cases, parents opposed the custody transfers (about $4 \%$ ), and in a few more cases $(11 \%)$, the parents remained passive (could not be reached/did not clarify their position).

There are large differences in how the decisions are formulated, and the text volume can vary from two to just over 10 pages. The longer texts are often decisions in which one or both parents opposed the claim for custody transfer. In some decisions, it only appears that "it is obviously best that the current arrangement remains in place" or "the foster parents are suitable for the role of specially appointed guardians" without the basis of the assessment being explicitly reported. The most concise decisions do not state how long the child has been placed in foster care, what the connection to the foster parents is, or the child's standpoint. The court is obliged to state the parties' claims and reasons for the judgement to justify the court's decision (SFS 1942, 740, Code of Judicial Procedure). However, our study shows that, in several cases, the court did not consider the child's wishes in the overall assessment or at least did not consider it important enough to be taken into account in the decision (cf. Wissö and Johansson 2018).

\subsection{Discourses in Social Practice}

What concepts and linguistic representations are used to shape children's needs and parental rights, and what kind of discursive practices do these represent? Our analysis 
identified three key discursive practices: the best interests of the child, reunion and social relationships, and one home-one family.

\subsubsection{The Best Interests of the Child}

The best interests of the child shall be decisive in the case of care and treatment intervention (SFS 2001, Social Services Act, 453). This means that children have the right to be heard and that their thoughts and wishes should be taken seriously. The best interests of the child must be apparent in the decision, and the decision has to be based on a balanced assessment of research, professional experience, the child's needs and wishes, and the parents' ability and wishes. All 89 decisions were studied to establish whether the child's wishes, directly or indirectly, were described and how this was understood in the decisions. In the 25 dispute decisions (in which the parents opposed the custody transfer), children stated their wishes in almost half $(48 \%)$ of the cases. In terms of the total number of decisions, only $29 \%$ of the children clearly stated their opinion regarding the custody transfer.

Our study shows that the child's views were mainly described indirectly, i.e., through other people's assessments, which was the case for 38 of the children (39\%). In these decisions, objective modality dominates. The child's situation is described as a truth, without the text clearly stating who is responsible for the statement or assessment. The following quote from the social services claim (as described in the decisions) illustrates this: "Kim has been placed in a foster home in accordance with the Social Services Act and, since 2010, has been constantly cared for and raised by Agneta and Gunnar. It is obviously best for Kim that the current situation continues and that custody is transferred to the foster parents.". The decision concerns a child born in 2005 who was 10 years old at the time of the custody transfer. Subjective modality (29\%) manifests through statements such as "the children state", "she wants" or "her wish". An example of this is Jonas, who was born in 1998 and was in foster care since the age of 10 . The custody transfer took place when Jonas was 16 years old. The social services claim states: "Jonas has stated that he wants his foster parents to be his guardians and that he regards them as his parents".

The fact that the modality differs between decisions in which the parents agree to a custody transfer and decisions in which the parents oppose a custody transfer indicates that it becomes less important to take into account the child's voice and wishes in decisions in which the social services and biological parents agree on what is best for the child. However, even in cases in which the parents oppose the custody transfer, as previously mentioned, the child's views are only apparent in just under half of the decisions studied. This shows that the prevailing discourse is still largely based on an adult perspective.

\subsubsection{Reunion and Social Relationships}

In the preparatory work for the Social Services Act and the Swedish Children and Parent Code, the importance of the child and their parents being reunited is emphasised, and the mere fact that the child has lived permanently in the foster home should not, in itself, result in the parents losing custody of their child. It is further stated that "it should not be possible to transfer custody from parents who maintain good contact with the child ... " (Goverment Bill 1981, 82:168, pp. 39-40). In all but one of the 20 cases, the parents' wishes are reported in the decisions. When the parent's standpoint is discussed, it is about parents having difficulties understanding the purpose of the custody transfer $(20 \%)$, or parents who do not trust the foster parents $(10 \%)$ or are worried that the custody transfer will negatively impact their own relationship with their child (10\%). Some parents want a reunion with their child $(20 \%)$, while other parents understand that their child must remain in foster care, although they want to remain as guardians and be involved in decisions concerning their child (35\%). Despite the emphasis that parents should not be concerned about losing their child, our study of current decisions in which parents opposed a custody transfer shows that parents' wishes do not seem to affect the outcome in the cases. 
District court decisions also allow for ambiguous interpretations regarding how the contact between child and parent is to be understood in relation to the custody issue. District courts sometimes use statements such as "the contact between the child and parent is not of such a nature/character that it excludes a custody transfer". Similar statements can be found in decisions in which children and parents have regular contact, as well as in decisions in which the relationship between child and parent is poor. Thus, the decisions do not provide any guidance on how the legislation should be interpreted (cf. Wissö and Johansson 2018). In several decisions (55\%), the district courts also discussed the child's right to stability and safeguarding and use closely related terms such as attachment, need for support, and positive development. Here is an extract from a district court decision regarding three siblings. The children are 3, 4, and 5 years old and, at the time of custody transfer, had been placed in their respective foster homes for 3 years.

"/ ... . However, the children still have a great need for support and safeguarding in order to be able to continue their positive development. Thus, their development would be negatively affected if they were forced to leave their foster homes and the people to whom they are attached and feel safe. / . . / A transfer of custody to each foster home would therefore create better conditions for safeguarding and continuity in the children's lives."

This decision indicates that the legislator's intentions to reunite the child with the biological parents are subordinate to the importance of continuity and permanence in the foster home. Continuity is measurable in years and months. A sense of belonging is more elusive and involves multifaceted emotions that are not limited to a few relationships. However, the fact that children feel a sense of belonging with their foster parents does not exclude the possibility that children could feel a sense of belonging with their biological parents and grandparents and other adults (cf. Andersson 1998).

The assessments of sense of belonging, continuity, and safeguarding in the decisions are presented as both objective truths and subjective experiences, and no single modality is dominant. The objective truths are described as follows: "/ . . / based on their need for safeguarding, in the long term, it must obviously be considered the best / . . /"; i.e., the assessment is distanced from the affected person and is presented as a fact. The subjective modality has an agent and is clarified in the decisions, for example, through information such as "according to the social secretary" or "the district court considers". There are strong indications that intertextuality plays a crucial role in linguistic representation. Concepts such as safeguarding, continuity, and attachment are recurring themes in many (55\%) of the decisions, without the specification of their meaning in each individual case.

\subsubsection{One Home-One Family}

We call the third discourse that emerges in our analysis one home-one family. Prominent statements here are "is settled" and "regards it as his home", and these statements can be found in $75 \%$ of the decisions. In this context, 'is settled' means that the child regards the foster home as his/her own home and the child feels safe with the foster parents or regards the foster family as his/her own family.

"Alex Jonsson has lived permanently with Mia Andersson and Jan Andersson for almost 5 years. The investigation shows that he is settled in the foster home. He has a safe and close attachment to both his foster parents and regards the foster home as his own home."

In addition to the child being settled and regarding the foster home as his own home, this quote also states that the child has a safe and close attachment to his foster parents. The attachment theory generally plays a crucial role in assessing the child's need for long-term and secure relationships. However, in several decisions in which this is discussed, the quality of the attachment is not clarified in the same clear way as above. Instead, it is briefly stated that the child is attached to their foster parents. Here, the manifest intertextuality appears with great clarity; i.e., text and descriptions are reproduced in different instances 
without their meanings being declared. That the child "is settled", "regards the home as his own home" and "feels greater emotional stability than in the home of origin" are statements that can be found in the preparatory work for the legislation, in the social services' claim and in the district court's reasoning.

There are, of course, variations in how the social services describe the children's situation. In some of the decisions, the modality is subjective and it would appear that it is the social services that are assessing that the children are settled or that the children themselves state that they want to remain in the foster home. However, objective modality dominates, for example, in statements such as "he is settled and regards the foster home as his own family". The child's views are described as an objective truth, without any clear agent in the text. In the district court's reasoning, reference is often made to the investigation (in court or the social services' investigation) and that it "appears from the investigation that" the child is settled in the foster home. This shows another side of intertextuality, i.e., that social services' reports are transformed into a truth in district court decisions, regardless of whether the description had a subjective or objective modality in the social services' claim.

The fact that linguistic representations of "perceive as their home" or "see as their family" play a decisive role in the decisions is problematic for several reasons. One reason is that these descriptions do not, in themselves, account for the quality of relationships and home life. Another reason is that these representations indirectly signal, as previously mentioned, that children can feel they are residing in only one home and feel a sense of belonging to only one family. Thus, the decisions are largely based on traditional nuclear family ideals, despite the emergence of new forms of family and research that shows that children placed in foster care, and children with separated parents, can feel a sense of belonging in multiple families at the same time (Andersson 1998; Larsson Sjöberg 2000).

\section{Discussion}

There is political consensus that children in out-of-home care have a right to stability and safeguarding, and that this must be prioritised by the social services. The study includes a survey of decisions from eight district courts that show that custody transfers are taking place at increasingly younger ages, after shorter stays in foster homes, and that there has been an increase in custody transfers regarding children placed in foster homes later in life. Furthermore, it appears that parents largely agree $(65 \%)$ or are passive $(11 \%)$ about custody transfers. The fact that parents do not oppose being deprived of the custody of their children could indicate that the social services prefer to initiate custody transfers in cases in which the parents agree to such a transfer.

\section{Discourses in District Court Decisions}

Our analysis has identified three dominant discourses that guide district court decisions. The first discourse, the best interest of the child, describes how the issue of custody transfer is still viewed from an adult perspective. This is particularly the case when parents and social services agree that a custody transfer should take place. Even in cases in which parents oppose a decision regarding custody transfer, the child's standpoint can only be seen in fewer than $50 \%$ of the decisions analysed. There may be reasons for not including the child, for example, for not placing the child in the middle of a conflict. However, the idea that this would be a motive in such a large proportion of the decisions is not reasonable. Rather, the results indicate that children's rights and will are still being neglected, and that there is a great need to intensify and deepen the work of involving and hearing children in accordance with the Convention on the Rights of the Child. Such work requires expertise and reflection on how questions are asked, as well as how children's voices are understood and mediated.

In the second discourse, reunification and social relationships, we show how parents' wishes and motives for or against a custody transfer are mentioned in the decisions but do not affect the outcomes in the cases. Furthermore, it appears that a district court's 
grounds for a custody transfer are often centred around concepts such as continuity, a sense of belonging, and attachment. Continuity refers to years and months, while sense of belonging and attachment are qualitative aspects that are more difficult to comprehend and whose meaning is not further defined. Additionally, the importance of a sense of belonging and attachment that children can feel in relation to their relatives and other important people in their social network is often overlooked. In order for an 18-year-old to not feel alone on the verge of adulthood (when the foster home's assignment has usually ended), it is important to pay attention to and help the young adult to maintain relationships already established while they are still living in the foster home.

We call the third discourse one home-one family. Salient statements in this discourse are that the child is "settled" and regards the foster home as "his own home". These statements can be found in the preparatory work for the legislation and are repeated in the social services' claim and in the district court's reasoning. Our interpretation is that this is a discursive practice that stems from the preparatory work for the legislation and that it is applied relatively uncritically. The manifest intertextuality, i.e., references to preparatory work, legitimises the discursive practice that risks overlooking the wishes of both children and parents when a custody issue is to be decided. The fact that concepts and statements are reproduced can partially be seen as justified in the district court's reasoning, in which references are made to preparatory work and legislation. However, it is noteworthy that the social services, in their claim to the district courts (that is, in their own text production), replicate the same concepts. Here, we see how discursive and social practices in interaction affect and reinforce each other. Another problem is that terms such as "settled" and regarding the foster home as "their own home" are representations that signal that children can only feel they are residing in one home and feel a familial sense of belonging to one family. This can be seen as a narrow and traditional interpretation of what is meant by family affiliation, which risks excluding other forms of family, beyond the nuclear family. It could be children whose parents have separated, as well as conditions for growing up in which the extended family and relatives play a more prominent role (Johnsdotter 2015).

\section{Conclusions}

Criticism of discursive and social practice in matters regarding custody transfers does not contradict the fact that a change of guardians can be the best way to ensure that children receive a safe and stable upbringing. Where reunification with biological parents is not an option, custody transfer gives children a more normalised existence beyond community care. However, professional practice, in both the social services and in court, requires considerations of how concepts and statements are applied and given meaning in cases that have such far-reaching implications for children and young people's continued lives. Otherwise, there is a risk that the debate that followed the high-profile Esmeralda case will engender more rapid routine-based investigations that fail to acknowledge both the intentions of the legislation and the best interests and wishes of children. There is no doubt that, while children's rights are being strengthened, there is a process of deprofessionalisation of social work. Professional knowledge based on research, best practice, and ethical values are challenged in organizations where increased administration, standardised assessment methods, and reduced scope for professional assessments are a reality (cf. Lauri 2016).

Of course, there are differences in how decisions are formulated and how the social workers describe the children's situation. The sample in this study does not provide a comprehensive overview but rather a reasonable basis for highlighting that certain discursive practices guide the handling of custody transfers. This, combined with the new legislation aimed at increasing the number of custody transfers, shows that there is a need for further research that examines the preconditions for, and long-term consequences of, custody transfers, for children, biological parents, and new guardians. 
Author Contributions: Both authors have contributed equally to this research. Both authors have read and agreed to the published version of the manuscript.

Funding: This research received no external funding.

Institutional Review Board Statement: Not applicable.

Informed Consent Statement: Not applicable.

Data Availability Statement: Not applicable.

Conflicts of Interest: The authors declare no conflict of interest.

Ethical Statement: This study examines district court decisions that are in the public domain in Sweden. No information has been obtained from individuals or professional social workers. Analysis of public documents does not require ethical approval due to The Act concerning the ethical review of research involving humans (The Swedish Code of Statutes (SFS), 2003:460). This is not a medical study, which requires approval in accordance with the Declaration of Helsinki.

\section{References}

Andersson, Gunvor. 1998. Föräldrakontakt och familjetillhörighet ur ett fosterbarns perspektiv (Parental contact and family affiliation from a foster child's perspective). Socialvetenskaplig Tidskrift 1: 3-23.

Biehal, Nina. 2014. A sense of belonging: Meanings of family and home in long-term foster care. British Journal of Social Work 44: 955-71. [CrossRef]

Carlemalm, Victoria. 2020. Privata utredare tjänar pengar på utsatta barn (Private investigators make money on vulnerable children). Dagens Nyheter. April 23. Available online: https://www.dn.se/asikt/privata-utredare-tjanar-pengar-pa-utsatta-barn/ (accessed on 25 April 2020).

Dozier, Mary, and Oliver Lindheim. 2006. This is my child: Differences among foster parents in commitment to their young children. Child Maltreatment 11: 338-45. [CrossRef] [PubMed]

Espvall, Majen. 2018. Professional strategies and neoliberal challenges in Swedish social work practice. In Neoliberalism, Nordic Welfare State and Social Work. Current and Future Challenges. Edited by Masoud Kamali and Jessica H. Jönsson. London: Routledge, pp. $148-58$.

Fairclough, Norman. 1992. Discourse and Social Change. Cambridge: Polity.

Fyhr, Rebecka. 2020. Socialsekreterare måste undervisa i domstolar (Social workers must teach in courts). Dagens Nyheter. April 23. Available online: https://www.dn.se/asikt/socialsekreterare-maste-undervisa-i-domstolar/ (accessed on 25 April 2020).

Goverment Bill. 1981. Om Vårdnad och Umgänge m.m. (About Custody and Contacts etc.); Stockholm: Swedish Parliament. 82:168. Available online: https:/ / www.riksdagen.se/sv/dokument-lagar/dokument/proposition/om-vardnad-och-umgange-mm_ G503168 (accessed on 18 September 2019).

Government Bill. 2002. Stärkt Skydd för Barn i Utsatta Situationer m.m. (Strengthened Protection for Children in Vulnerable Situations, etc.); Stockholm: Swedish Parliament. 03:53. Available online: http:/ / data.riksdagen.se/dokument/GQ0353 (accessed on 18 September 2019).

Government Bill. 2020. Regelbundna Överväganden av Vårdnadsöverflyttning och Särskilda Lämplighetskrav för Offentliga Biträden (Regular Considerations of Custody Transfer and Special Requirements for Public Assistants); Stockholm: Swedish Parliament. 21:35. Available online: https://www.riksdagen.se/sv/dokument-lagar/dokument/proposition/regelbundna-overvaganden-avvardnadsoverflyttning_H80335 (accessed on 20 May 2021).

Griffin, Julie D. 2004. Growing Up in Foster Care: A Qualitative Study of the Relational World of Foster Youth. Austin: The University of Texas. Available online: https:/ / repositories.lib.utexas.edu/bitstream/handle/2152/2002/griffinjd042.pdf?sequence=2\&isAllowed=y (accessed on 4 March 2019).

Johnsdotter, Sara. 2015. European Somali Children Dumped? On families, parents, and children in a transnational context. European Journal of Social Work 18: 81-96. [CrossRef]

Lagercrantz, Denise. 2020. Skyll inte på lagen när det är socialsekreterarnas fel. (Do not blame the law when it is the social workers fault). Dagens Nyheter. April 21. Available online: https:/ /www.dn.se/asikt/skyll-inte-pa-lagen-nar-det-ar-socialsekreterarnas-fel/ (accessed on 25 April 2020).

Larsson Sjöberg, Kristina. 2000. Barndom i Länkade Familjesystem. Om Samhörighet och Åtskillnad (Childhood in Linked Family SystemsConnection and Separation). Gothenburg: Department of Social Work, University of Gothenburg. Available online: https: //gupea.ub.gu.se/handle/2077/12494 (accessed on 5 March 2019).

Lauri, Marcus. 2016. Narratives of Governing: Rationalization, Responsibility and Resistance in Social Work. Umeå: Umeå University.

Mattsson, Titti. 2010. Rätten till Familj Inom Barn- Och Ungdomsvården. (The Right to a Family in Child and Youth Care). Malmö: Liber.

National Board of Health and Welfare. 2006. Vårdnadsöverflyttningar för Barn Placerade i Familjehem. (Custody Transfers for Children in Foster Care); Stockholm: Socialstyrelsen.

National Board of Health and Welfare. 2015. Nya Bestämmelser för den Sociala Barn- och Ungdomsvården-Uppföljning av 2013 års Ändringar av SoL och LVU New Regulations Regarding Children and Youth Care-Follow-up of the 2013 Changes of the 
Social Services Act and Care of Young Persons Act. Available online: http:/ /www.Socialstyrelsen.se/Lists / Artikelkatalog/ Attachments/19962/2015-12-6.pdf (accessed on 28 May 2019).

National Board of Health and Welfare. 2020. Statistik om socialtjänstinsatser till barn och unga 2019 (Statistics on Social Services Treatment for Children and Youth 2019). Available online: https://www.socialstyrelsen.se/statistik-och-data/statistik/statistikamnen/ barn-och-ungdom/ (accessed on 8 May 2021).

Ponnert, Lina, and Kerstin Svensson. 2015. Standardisering som lösning (Standardisation as a solution). In Människobehandlande Organisationer: Villkor för Ledning, Styrning och Professionellt Välfärdsarbete (Human Service Organisation: Conditions for Management, Governance and Professional Welfare Work). Edited by Staffan Johansson, Peter Dellgran and Staffan Höjer. Stockholm: Natur \& kultur.

Risholm Mothander, Pia, and Anders Broberg. 2015. Små Barns Behov av en Långsiktig Trygg Bas: En Barnpsykologisk Kunskapsöversikt (Young Children's Need for a Long-Term Safe Base: A Child Psychology Knowledge Overview). Stockholm: Department of Psychology, Stockholm University.

Rolock, Nancy, and Kevin R. White. 2016. Post-permanency discontinuity: A longitudinal examinations of outcomes for foster youth after adoption or guardianship. Children and Youth Services Review 70: 419-27. [CrossRef]

Sallnäs, Marie, and Stefan Wiklund. 2018. Socialtjänstmarknaden-om Marknadsorientering och Konkurrensutsättning av Individ- och Familjeomsorgen (The Social Services Market-Market Orientation and Exposure to Competition in the Social Services). Stockholm: Liber.

SFS. 1942. Rättegångsbalk (Code of Judicial Procedure). Stockholm: Justitiedepartementet. 740. Available online: https://www riksdagen.se/sv/dokument-lagar/dokument/svensk-forfattningssamling/rattegangsbalk-1942740_sfs-1942-740 (accessed on 3 October 2019).

SFS. 1949. Föräldrabalk (Children and Parent Code). Stockholm: Justitiedepartementet. 381. Available online: https://www.riksdagen.se/ sv/dokument-lagar/dokument/svensk-forfattningssamling/foraldrabalk-1949381_sfs-1949-381 (accessed on 3 October 2019).

SFS. 2001. Socialtjänstlag. (Social Services Act). Stockholm: Socialdepartementet. 453. Available online: https://www.riksdagen.se/sv/ dokument-lagar/dokument/svensk-forfattningssamling/socialtjanstlag-2001453_sfs-2001-453 (accessed on 19 September 2019).

SOU. 2009. Lag om stöd och Skydd för barn och unga, LBU (Law on Support and Protection for Children and Youth). 68. Available online: https://www.regeringen.se/rattsliga-dokument/statens-offentliga-utredningar/2009/07/sou-200985 (accessed on 22 September 2019).

Thunman, Elin. 2016. Coping with Moral Stress in the Swedish Public Services. Nordic Journal of Working Life Studies 6: 59-77. [CrossRef]

Wissö, Therese, and Helena Johansson. 2018. Transferring custody from birth parents to foster parents-an ambiguous matter. Journal of Social Welfare and Family Law 40: 321-39. [CrossRef]

Wissö, Therese, Johansson Helena, and Ingrid Höjer. 2019. What is a family? Constructions of family and parenting after a custody transfer from birth parents to foster parents. Child \& Family Social Work 24: 9-16. 